\title{
Modern Çağın Sorunu Olarak “Çocukluk Çağı Obezitesi”: Sosyal Hizmet Uzmanı ve Diyetisyen İşbirliğinin Önemi
}

\author{
"Childhood Obesity" as the Problem of the Modern Age: The Importance of Cooperation between \\ Social Worker and Dietitian
}

Filiz Yıldırım ${ }^{1}$, Emine Sadak ${ }^{2}$

Geliş tarihi/Received: 27.08.2020 • Kabul tarihi/Accepted: 21.09.2020

\section{ÖZET}

Modern çağın en yaygın hastalıklarından biri haline gelen obezite, çocukluk çağında erken yaşlarda görülmekte ve yetişkinlik döneminde diyabet, kalp damar hastalıkları, hipertansiyon ve bazı kanser türleri gibi pek çok kronik hastalığa neden olmaktadır. Çocukluk çağı obezitesi; nedenleri ve sonuçları ile çok boyutlu ve bütüncül bir değerlendirme ve dolayısıyla multidisipliner bir çalışma gerektirir. Bu bağlamda çocukluk çağı obezitesi ile mücadelede etkili bir sonuca varmak için bu konudaki profesyonel sağlık çalışanlarının müdahale sürecine dahil olması ve iş birliği yapması önemlidir. $\mathrm{Bu}$ derleme çalışmanın temel amacı, bu profesyonel sağlık ekibine uzman yetiştiren sosyal hizmet odağında çocukluk çağı obezitesini, biyopsikososyal açıdan değerlendirmektir. Ayrıca çocukluk çağı obezitesi ile mücadelede diyetisyen ve sosyal hizmet uzmanı işbirliğinin önemini ulusal ve uluslararası literatür ışığında açıklamaktır. Sonuç olarak çocukluk çağında obezite ile mücadelede önemli bir yeri olan sosyal hizmet uzmanı ve diyetisyen iş birliği, çocukların sağlıklı yaşam yıllarını artırmak için yapılan müdahalelerin daha etkili olmasına katkıda bulunur.

Anahtar kelimeler: Çocuk, diyetisyen, obezite, sosyal hizmet uzmanı

\begin{abstract}
Obesity, which has become one of the most common diseases of the modern age, is seen in early childhood and causes many chronic diseases such as diabetes, cardiovascular diseases, hypertension and some types of cancer in adulthood. Childhood obesity requires a multidimensional and holistic evaluation and therefore a multidisciplinary work with its causes and results. In this context, in order to reach an effective result in combating childhood obesity, it is important that professional healthcare workers participate in the intervention process and cooperate. The main objective of this review study is to evaluate childhood obesity from a bio-psychosocial perspective in the focus of social work, which trains specialists for this professional healthcare team. In addition, it is also to explain the importance of cooperation between dietitians and social workers in the fight against childhood obesity in the light of national and international literature. As a conclusion, the cooperation of social worker between dietitians that have an important place in the fight against obesity in childhood contributes to the more effective interventions made to increase the healthy life years of children.
\end{abstract}

Keywords: Child, dietitian, obesity, social worker

1. İletişim/Correspondence: Ankara Üniversitesi, Sağllk Bilimleri Fakültesi, Ankara, Türkiye • E-posta: fyildirim@ankara.edu.tr

2. Diyarbakır Aile, Çalışma ve Sosyal Hizmetler İl Müdürlüğü, Diyarbakır, Türkiye (ㄱ) https://orcid.org/0000-0002-6987-9485 (1) https://orcid.org/0000-0002-4297-9814 


\section{GİRIŞ}

Modern çağın getirdiği yeni yaşam tarzı ve beslenme alışkanlıklarının olumsuz etkilerinin ürünü olan obezite, çağımızın en yaygın hastalıklarından biri haline gelmiştir. Özellikle gelişmiş ve gelişmekte olan ülkelerde obezite prevalansı hızlı bir artış göstermiş (1) ve 1975-2014 yılları arasında yaklaşı üç kat artmiştır (2).

Obezite, Dünya Sağlık Örgütü (DSÖ) tarafından "sağlığı bozabilecek anormal ya da aşırı yağ birikimi” olarak tanımlanmaktadır (3). Sağlık Bakanlığı tarafından yapılan obezite tanımında ise "genel olarak bedenin yağ kütlesinin yağsız kütleye oranının aşırı artması sonucu boy uzunluğuna göre vücut ağırlığının arzu edilen düzeyin üstüne çıkması” olarak ifade edilmektedir (4). Her iki tanımda da obezite, vücutta biriken aşırı yağ miktarı olarak ifade edilmektedir.

Beslenmenin, insan sağlığı ve gelişimi için önemi bilinmektedir. Obezite tanımından da yola çıkılırsa beslenmenin, obezite ile mücadelede temel odak noktası olduğu görülmektedir. Obezite etiyolojisine bakıldığında temelde günümüz teknolojik gelişmeleri ve "fast food" olarak adlandırılan yeni yeme alışkanlıkları öne çıkmaktadır (1). Sağlıksız beslenme sonucu oluşan bu hastalığın yaygın bir biçimde görülmeye başlaması; bu hastalığa bağlı diyabet, kalp damar hastalıkları, hipertansiyon, bazı kanser türleri gibi hastalıkların toplumda daha fazla görülmesine ve bu hastalıklara bağlı mortalite oranlarında artışa neden olmaktadır (5-7). Bu hastalığın çocukluk çağında da görülmeye başlaması ve hızla artış göstermesi ülkeleri obezite ile mücadele konusunda daha fazla harekete geçirmiştir.

Çoğu sağlık otoritesi, fazla kilonun nedenlerinin; çevresel olduğunu, yiyeceklere kolay erişime izin veren ve hareketsizliği teşvik eden bir dünyada yaşamakla ilgili olduğunu belirtmektedir (8). Yeme alışkanlıklarındaki değişiklikler; yaşam tarzı, sosyal çevre ve diğer sosyal ve toplumsal faktörlerdeki değişikliklerle ilgilidir (9). Obezojenik çevre olarak da ifade edilen ve bireyi sağlıksız yemek yemeye ve hareketsiz bir yaşama teşvik ederek obeziteye neden olan çevresel etmenler çocukluk çağı obezitesi ile ilgili yapılan çalışmalarda sık sık belirtilmektedir. Bu çevresel etmenlerin etkisi modernleşme ile birlikte daha fazla görülmektedir $(7,10,11)$. İşlenmiş besine erişimi ve tüketimi arttıran, taze besin tüketimini ve besinleri hazırlama süresini azaltan, fiziksel aktivite için daha az zaman ve daha az alan sağlayan değişikler özellikle yaşam tarzında büyük farklılıklara yol açmaktadır (10,12). Bu değişimlerden en çok etkilenen gruplardan biri çocuklardır. Çocukların özellikle paketlenmiş aşırı şeker ve yağ içeren yiyeceklere ve içeceklere olan ilgisi ve teknolojik gelişmelerle birlikte bilgisayar, televizyon gibi araçlar ile daha fazla zaman geçirerek hareketsiz bir yaşam sürdürmeleri çocukluk çağında obezitenin en önemli güdüleyicisi olarak gösterilmektedir $(6,13,14)$. Koç ve ark. (15) tarafından yapılan bir çalışmada günde üç saatten fazla televizyon izleyen kız çocuklarının \%71’inin fazla kilolu olduğu belirtilmiştir.

Özellikle çocuk yaşlarda sağlıklı beslenme alışkanlığının geliştirilmesi, çocuk sağlığı için en önemli belirleyicilerdendir. Araştırmalar çocukluk çağında edinilen beslenme alışkanlığının yetişkinlikte de devam ettiğini ve yetişkinlikteki sağlık problemlerini de olumsuz etkilediğini göstermektedir $(1,5,16,17)$. Ayrıca çocukluk çağında obez olanların \%30'unun yetişkinlik döneminde de obez olma olasılığı vardır (16).

Çocuklukçağı obezitesi hem metabolik birçok hastalığa yol açmakta hem de özellikle özgüven eksikliği gibi psikolojik sorunlara neden olmaktadır. Özgüven eksikliği, çocukların çevreye uyum sağlamalarını zorlaştırmaktadır. Ayrıca sosyalleşme ve bilişsel gelişimin önemli olduğu çocukluk çağında obez çocukların akran zorbalığına maruz kalması olumlu bir benlik algısı oluşumunda ve sosyalleşme sürecinde önemli bir engel olarak karşımıza çıkmaktadır $(2,11)$.

Diğer yandan obezitenin beslenme odaklı bir hastalık olduğu yaygın bir kanı olsa da çocukluk çağında 
obeziteye neden olan etmenler çok boyutludur (18-20). $\mathrm{Bu}$ etmenler; teknolojik gelişmelerle birlikte daha az hareketli yaşam biçimi, ailesel ve psikolojik faktörler, genetik yapı, besin üretim yöntemleri, kültürel faktörler, ekonomik koşullar, bilişsel ve davranışsal özellikler olarak sıralanabilir $(5,10)$. Bu boyutları ile obezitenin sadece beslenme odağında değil biyopsikososyal boyutlarıyla da değerlendirilmesi gereken önemli bir hastalık olduğu belirtilebilir.

Obezite, tedavisi mümkün; ancak zor bir hastalıktır. Bu nedenle dünyanın birçok yerinde önemli bir sorun haline gelen obezite ile mücadele yöntemi, çok boyutlu ve dolayısıyla multidisipliner bir çalışma gerektirir. Bu nedenledir ki obezite ile mücadelede etkili bir sonuca varmak için müdahale sürecinde doktor, diyetisyen, hemşire, çocuk gelişimci, psikolog, sosyal hizmet uzmanı gibi birçok profesyonel paydaş sorumluluk sahibidir. Obezitenin tıbbi tedavi yaklaşımı ile tedavi edilmesi tekrar oluşmaması açısından oldukça önemlidir. Diyetisyenlerin üzerinde titizlikle çalıştığı obezitenin önlenmesinde ve tedavisinde bireylerin beslenme alışkanlıkları değiştirilmeye çalışılırken obeziteye neden olan diğer etmenlerin ortadan kaldırılmasına konu ile ilgili diğer profesyonellerin de yardımcı olması gerekir. Bu nedenle obezite ile mücadelede hastalığın sadece tıbbi ve beslenme boyutuna yönelik çalışmaların yürütülmesi yeterli değildir. Zira obez bireylerin aynı zamanda içinde bulunduğu çevresel faktörlerin incelenmesi, yeme bozukluğunun çok boyutlu nedenlerinin araştırılması ve buna uygun etkili müdahalelerin geliştirilmesi gerekmektedir. Özellikle son yllarda ülkeler obezojenik çevrenin obezite üzerindeki etkilerine ilişkin çalışmalar yürütmeye başlamıştır $(7,11)$. Obezite ile mücadelede obezojenik çevre, sosyal hizmetin mesleki müdahale ve yöntemlerindeki odak noktasını oluşturur. Bu bağlamda diyetisyenler ile birlikte sosyal hizmet uzmanlarının da müdahale sürecine aktif katılması ve işbirliği yapması önemlidir. Son yıllarda yapılan araştırmalar $(13,17,21-24)$ obezite ile mücadelede profesyonel sağlık ekibinin bir parçası olarak sosyal hizmet uzmanlarının rolü üzerinde durmaktadır (17). Özellikle tıbbi sosyal hizmet uzmanları, çeşitli sağlık sorunları nedeniyle sağlık kuruluşlarına başvuran bireylerin sağlık sorunlarının yanında psikolojik ve sosyal sorunlarının çözümünde de etkili rol oynamaktadırlar (25). Buradan hareketle mevcut çalışmanın temel amacı, çocukluk çağı obezitesini sosyal hizmet odağında biyopsikososyal açıdan değerlendirmek ve yapılan müdahalelerde diyetisyen ve sosyal hizmet uzmanı işbirliğinin rolünü ve önemini açıllamaktır.

\section{Dünya'da ve Türkiye'de Çocukluk Çağı Obezitesi}

Dünya Sağlık Örgütü (26) verilerine bakıldığında daha önceleri, gelişmiş ülkelerin bir sağlık sorunu olarak görülen obezitenin son ylllarda gelişmekte olan ülkelerde de yaygın bir şekilde görüldüğü tespit edilmiştir. Dünya Sağlık Örgütü’nün obezite verilerine göre 2008 yılında obez insan sayısı 400 milyon iken 2015 yılında bu sayı, 700 milyona yükselmiştir.

Sadece yetişkinlik döneminde değil çocukluk çağında da artış gösteren obezite oranları incelendiğinde 2016 yılında 5-19 yaş arası fazla kilolu ve obez olarak ifade edilen 340 milyondan fazla çocuk ve ergen bulunmaktadır. Ayrıca 2019 yılı verilerine göre ise beş yaşın altında 38 milyon obez çocuk olduğu tahmin edilmektedir (3). Obezitenin en sık görüldüğü Amerika Birleşik Devletleri’nde 1976 ve 2000 yılları arasında çocuklarda obezite iki kat, ergenlerde üç kat artış göstermiştir (1,12). Avrupa kıtasındaki çocuklara ilişkin obezite verilerine bakıldığında ise \%16-22'sinin fazla kilolu ve \%4-6’sının obez olduğu tahmin edilmektedir (27).

Obezite, dünyanın birçok yerinde olduğu gibi ülkemizde de yaygın bir hastalık haline gelmiştir. Türkiye Beslenme ve Sağlık Araştırması 2017 yılı raporuna göre obezitenin erkeklerde görülme oranı \%13.7 iken kadınlarda bu oran \%20.9'dur. Türkiye'de toplam obezite oranının ise \%17 olduğu belirtilmektedir (28). Türkiye Beslenme ve Sağlık Araştırması 2010 yılı raporuna göre 0-5 yaş arasında obezite görülme sıklığının \%8.5 (erkek \%10.1, kız \%6.8), 6-18 yaş arasında obezite görülme sıklığının ise \%8.2 olduğu tespit edilmiştir (29). 
Ülkemizde obeziteye ilişkin yapılan bir diğer çalışma ise 2009 yılında gerçekleştirilen Türkiye Okul Çağı Çocuklarında Büyümenin İzlenmesi (TOÇBİ) araştırmasıdır. Bu kapsamda hedef grup olan 6-10 yaş grubu çocuklar arasında kilolu olma oranı \%14.3, obezite oranı ise \%6.5 olarak bulunmuştur. TOÇBİ (2009) araştırmasının sonuçları ülkemizde her beş çocuktan birinin kilolu olmaya bağlı hastalıklar açısından risk altında olduğunu göstermektedir (30).

Çocukluk çağı obezite araştırmalarına bir diğer önemli örnek Türkiye Çocukluk Çağı Obezite Araştırma Girişimi Çalışması'dır. Bu çalışmada 2016 yılı verilerine göre Türkiye'de 7-8 yaşındaki çocukların \%14.6'sının fazla kilolu ve \%9.9'unun ise obez olduğu tespit edilmiştir (5).

\section{Çocukluk Çağı Obezitesinde Diyetisyenlerin Rolü}

Sağlıklı beslenme, sağlıklı bir insan gelişimi için elzemdir. Yaşam döngüsü boyunca bireylerin sağlıklı bir yaşam sürdürmelerinde insan vücudunun ihtiyaç duyduğu miktarlarda sağlıklı besinlerin tüketilmesi gerekmektedir (5). İnsanların daha sağlıklı ve dengeli beslenmelerinde önemli bir yere sahip olan diyetisyenler, obezite ile mücadelede önemli bir yeri olan profesyonel meslek uzmanlarıdır. $\mathrm{Bu}$ mücadelede her meslek grubunun kendi mesleki sınırlılıkları dahilinde gerçekleştirdiği müdahale yöntemleri incelendiğinde, diyetisyenler özellikle bireylerdeki beslenme alışkanlıklarının değişmesine yardımcı olan diyet, beslenme eğitim programları hazırlamakta ve beslenme danışmanlığı yapmaktadırlar. Diyetisyenler, obez bireyleri tüketmeleri gereken doğru besinler, besin miktarları ve hareketli yaşam konusunda yönlendirerek sağlıklı beslenme alışkanlığı edindirmek için danışmanlık yaparlar $(6,16)$.

Obezite tedavisinde uygulanacak diyetin doğru bir biçimde uygulanması için diyetisyen tarafından verilen beslenme eğitimi, büyük önem taşır. Çocukluk çağında görülen obezite ile mücadelede diyetisyenin önerdiği beslenme tedavisi, çocuğun gelişim sürecini aksatmayan enerji ve besin ögelerini ayrıca fiziksel aktivitenin artırılmasını içerir (16). Çocukların yaş ve fizyolojik durumuna göre besinlerden edinilen enerji dengesinin sağlanması, öğünlerin düzenli olması, yağ ve şeker içeriğine sahip besinlerin azaltılması, sebze ve meyve tüketiminin düzenlenmesi, sıvı tüketiminin arttırılması gerekmektedir (16,31). Bu doğrultuda besin tüketimi ve beslenme önerilerini belirlemek ve uygulamak, bireylerin sosyoekonomik düzeyine göre ulaşabileceği sağlıklı besin kaynaklarına göre beslenme tedavisini planlamak, bu plan doğrultusunda doktorlara önerilerde bulunmak ve hatta doktorlara yönelik eğitimler düzenlemek diyetisyenin sorumluluğundadır (32). Aynı zamanda çocukların en çok zaman geçirdiği okulların yemekhanelerinde ya da kantinlerinde çocuklar için sağlıklı besinlerin bulundurulması ve bu konuda gerekli denetimlerin yapılmasının yine diyetisyen kontrolünde olması gerekmektedir (16).

Bazı çalışmalar besinlerden elde edilen aşırı enerji ve yağ miktarının, obezitenin gelişimi üzerinde önemli etkisinin olduğunu göstermektedir $(18,33)$. Çocukluk çağı obezitesinin beslenme odağında, biyolojik ve genetik faktörlere göre tedavi edilmesinde diyetisyenin rolü yadsınmamaktadır. Ancak biyolojik ve genetik faktörlerin yanı sıra psikolojik, sosyal, kültürel faktörlerin de odağa alınarak daha bütüncül bir değerlendirme yapılması önemlidir. Zira böyle bir değerlendirmeye bağlı olarak obeziteye karşı koruyucu önlemlerin alınması, beslenme alışkanlıklarının istenen yönde değiştirilmesi, sağlıklı beslenme alışkanlıklarının kazandırılması ve toplumsal farkındalık oluşturulması için biyopsikososyal yaklaşım önemlidir (34).

\section{Çocukluk Çağı Obezitesinin Biyopsikososyal Açıdan Değerlendirilmesi ve Sosyal Hizmet Uzmanlarının Rolü}

Çocukluk çağı obezitesi ile mücadelede sosyal hizmet uzmanlarının, profesyonel sağlık ekibinin bir parçası olarak sürece dahil olması önemlidir. Obez çocukların yaşam kalitesinin arttırılmasında gerekli sosyal hizmet müdahalelerini ve yöntemlerini geliştiren profesyonel sağlık çalışanı olarak sosyal hizmet 
uzmanları, obezite ile mücadelede çocuğu çevresi içerisinde değerlendirirler (13). Bu mücadelede önemle üzerinde durulması gereken ve obezojenik çevre olarak da ifade edilen bu çevre, sosyal hizmet uzmanlarının müdahale alanı kapsamında yer alır. Bu noktada belirtilmelidir ki sosyal hizmet uzmanları için özellikle çocuklarda görülen obeziteyi sadece beslenme ve fiziksel aktivite azlığına bağlı bir hastalık olarak görmemek önemlidir. Zira çocuğu yeme bozukluğuna iten çevresel faktörlerin de bu süreçte irdelenmesi gerekir. Bu nedenle sosyal hizmet uzmanları obezitenin gelişimini doğrudan ve dolaylı olarak etkileyen çevreleyicileri bütüncül olarak ele alıp biyopsikososyal müdahale yöntemleri geliştirmekten sorumludurlar (13,17).

Sosyal hizmet alanında oldukça yaygın olarak kullanılan biyopsikososyal yaklaşım, varolan sorunu çoklu boyutlarıyla değerlendirir (Şekil 1).

Zira böyle bir yaklaşım obezitenin sadece tıbbi boyutunu ele almaz. Obeziteye kaynaklık eden çevresel, sosyolojik ve psikolojik boyutları yani tıbbi olmayan boyutları da değerlendirir (34). Bu yaklaşım bireyleri etkileyen biyolojik faktörlerin ya da süreçlerin yanında bu bireylerin tedaviye aktif ve düzenli katılımını sağlamada sosyoekonomik düzeyin de incelenmesini sağlar (25).

Sosyal hizmetin temel yaklaşımlarından genelci, sistem ve ekolojik yaklaşım ile benzerlik taşıyan biyopsikososyal yaklaşım, tıbbi sosyal hizmet alanının temel müdahale yöntemidir (25). Sosyal hizmet

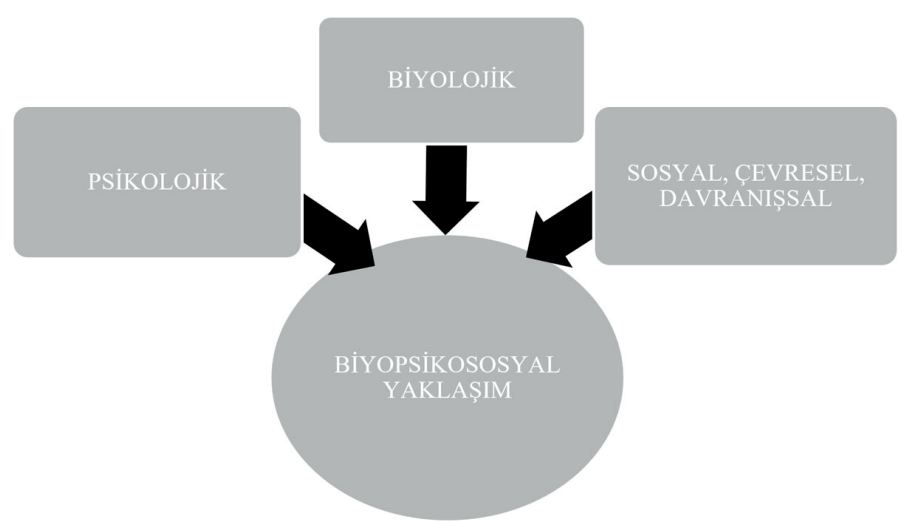

Şekil 1. Biyopsikososyal yaklaşım (25. ve 34. kaynaklardan uyarlanmıştır.) uzmanı bu yaklaşımı temel alarak obez çocuğun ailesini, okulunu, yaşadığı mahalleyi ve toplumun kültürel değerlerini de ele alır. Bu nedenle öncelikli olarak obez ya da fazla kilolu bir çocukla çalışırken, çocuğun bir aile sisteminin parçası olduğunu hatırlamak ve aile yaşam biçiminin de tedavi için ele alınması gerektiğini bilmek önemlidir. Bu süreçte ebeveynlere sağlıklı beslenme ve aktivite düzeylerinin artırılmasını öğretmek gerekebilir. Örneğin sosyal hizmet uzmanı bir çocuğa daha fazla sebze yemenin önemini öğretiyorsa, ebeveynler daha fazla sebze tüketmedikçe olumlu değişim, büyük olasılıkla gerçekleşemeyecektir. Çünkü çocuklarda sağlıksız beslenme alışkanlıklarının çoğu, ebeveynlerin yaşam biçiminden ve beslenme alışkanlıklarından kaynaklanmaktadır (13).

Aynı zamanda sosyal hizmet uzmanları çocukluk çağında obezite ile mücadele ederken güçlendirme temelli bir müdahale yöntemi geliştirebilmelidirler. $\mathrm{Bu}$ noktada özellikle belirtilmelidir ki güçlendirme sadece kişisel/psikolojik değil yapısal ve kültürel boyutları da içerir (35). Obezitenin özellikle psikolojik boyutu düşünüldüğünde obez çocuk ve ebeveynleri için obezite ile mücadele yıpratıcı olabilmektedir (13). Bu nedenle sosyal hizmet uzmanı; özgüven eksikliği, çevreye uyum sorunları, düşük benlik algısı, akran zorbalığı gibi obezitenin kaynakları olabilecek psikolojik süreçleri dikkate alarak bireysel düzeyde müdahalelerde bulunabilirler. Böylece bir çocuğun obeziteye bağlı yaşadığı psikolojik etkileri en aza indirmek için sosyal hizmet uzmanının; çocuğun ve ailesinin güçlü yönlerini görmesini sağlayarak kendi potansiyellerini açığa çıkarmaları açısından bu müdahaleler önemlidir (36). Ayrıca sosyal hizmet uzmanlarının obez çocuklara karşı toplumda var olan ayrımcı kültürel söylemlerin bilincinde olarak çocuğun çevreyle uyum sorunlarını en aza indirecek müdahale planı gerçekleştirebilmeleri de gerekir (34). Ayrıca ailelerin yemek kültürü, yaşadığı toplumun ve çevrenin yemek kültüründen ayrı düşünülemez. $\mathrm{Bu}$ nedenle ailelerin yemek kültürünü göz önünde bulundurarak müdahale planının yapılması da önemlidir (13). 
Sosyal hizmet uzmanının, çocukluk çağı obezitesi ile mücadelede dikkate alması gereken bir diğer husus da savunuculuk rolüdür. $\mathrm{Bu}$ bağlamda sağlıklı beslenmeyi engelleyen ve sağlıksız besinlere kolaylıkla erişime neden olan çevresel sistemlere karşı çocukların korunması da yapısal boyutta güçlendirme açısından önemlidir. Bu nedenle sosyal hizmet uzmanlarının okullarda çocukların daha sağlıklı besinlere ulaşmasında çocuk ve ailesi ile birlikte savunuculuk görevini yerine getirebilmeleri önem arz eder. Ayrıca sosyal hizmet uzmanının toplumda çocuğu aşırı şekerli ve yağlı yiyecekleri ve içecekleri tüketmeye özendirici reklam ve satış politikalarına karşı da savunucu rolünü üstlenmesi gerekmektedir (14). Buradan hareketle sosyal hizmet uzmaninin obezite ile mücadelede sadece bireysel boyutta (obez çocuk) değil bu boyutu da içerecek biçimde bireyin bulunduğu diğer sistemleri de odağına aldığı ifade edilebilir. Bu müdahaleleri gerçekleştirirken sosyal hizmet uzmanlarının diğer meslek gruplarıyla (doktorlar, diyetisyenler, hemşireler, fizyoterapistler, okullar, topluluklar ve ailelerle) ve sistemlerle iş birliği içinde çalışması, çocukluk çağında görülen obezite ile etkili bir biçimde mücadele için önem arz eder $(13,23)$.

Diğer yandan sadece sosyal hizmet uygulayıcılarının değil sosyal hizmet akademisyenlerinin de obezite oranlarını azaltmak için toplumu bilinçlendirmeye katkıda bulunmaları önemlidir. Özelikle obezite ile mücadelede çocuk ve ailesinin güçlendirilmesini hedefleyen önleme ve müdahale stratejilerinin geliştirilmesine ve aile, eğitim, ekonomi ve sağlık politikalarına kanıt temeli sağlama potansiyeli taşıyan araştırmalar yürütmeleri de önem arz eder (22).

\section{Diyetisyen ve Sosyal Hizmet Uzmanı İşbirliğinin Önemi}

Disiplinlerarası işbirliği, farklı disiplinlerin kendi profesyonel bilgi temelini de koruyarak hizmeti, etkileşim halinde birlikte sunması olarak ifade edilmektedir (21). Bu çalışmanın da konusunu oluşturan diyetisyen ve sosyal hizmet uzmanının çocukluk çağında obezite ile mücadelede önemi yadsinamaz. İki meslek grubu da müdahale yöntemlerinde farklılık göstermektedir (21). Ancak biyopsikososyal açıdan değerlendirildiğinde obezite ile mücadelede beslenme tedavisi tek başına bir çözüm olamamaktadır. Multidisipliner bir çalışma gerektiren obeziteye neden olan çoklu faktörlerin araştırılmasında diyetisyenlerin mesleki sorumlulukları ve görevleri önemli olmakla birlikte disiplinlerarası çalışmalarını gerektirir. Etkili bir müdahale yöntemi için diyetisyenden beslenme danışmanlığı alan obez çocuklarla yürütülecek mesleki çalışmalarda obeziteye neden olan genetik, çevresel, sosyal, psikolojik faktörlerin belirlenmesi, çok boyutlu bir tedavi planının oluşturulması ve takibini sağlamada sosyal hizmet uzmanları önemli sorumluluklar üstlenebilirler. Obeziteye neden olan bu faktörler incelendiğinde obezitenin \%2540 oranında genetik olarak ortaya çıktığı (2) göz önüne alındığında obezitenin biyolojik boyutunu değerlendirmede de sosyal hizmet uzmanları sağlık çalışanları ile iş birliği yaparak aile öyküsünün alınmasında rol üstlenebilirler. Aynı zamanda obezitenin genetik boyutunun yanında çevresel ve sosyolojik boyutuna ilişkin çalışmalar son yıllarda hız kazanmakta ve obezitenin obezojenik çevreye bağlı olarak ortaya çıktığı belirtilmektedir. Bireyin yaşadığı toplumun yemek kültürü, teknolojik gelişmeler, şehirleşme ile birlikte hareketsiz yaşam, paketlenmiş hazır besinlere erişimin kolaylaşması ve bu besinlerin tüketiminin artması, obezitenin kaynakları arasında siralanmaktadır $(7,10,11)$. Bu nedenle çocukluk çağında obezite değerlendirilirken sosyolojik boyut odağında çocuğun içinde yaşadığı piyasa sisteminin, politikaların, toplumun ve ailesinin de iyi analiz edilmesi gerekir. Aksi taktirde bireyde davranış değişikliğinin gerçekleştirilmesi mümkün olmayabilir. Obezite her ne kadar genetik ve çevresel faktörlere dayandırılsa da psikolojik boyutunun da göz ardı edilmemesi gerekmektedir. Zira özellikle çocukluk ve ergenlik çağında obez olmak, ciddi psikolojik travmalardan kaynaklanabilir. Nitekim stresli çocuklarda aşırı yemek yeme isteği görülebilir. $\mathrm{Bu}$ noktada özellikle belirtilmelidir ki obezite; çocuklarda depresyon, özgüven eksikliği, sosyal 
izolasyon gibi psikolojik sorunlara da neden olabilir (34). Bu nedenledir ki çocukluk çağında obezite ile mücadelede biyopsikososyal faktörler, başta diyetisyen ve sosyal hizmet uzmanları olmak üzere farklı meslek gruplarının işbirliğini gerektirir.

\section{SONUÇ VE ÖNERILER}

Sosyal hizmet uzmanları ve diyetisyenler arasındaki işbirliği, farklı bilgi temeline sahip uzmanların profesyonel yönelim ve müdahale yöntemleri arasındaki işbirliğinin bir örneğini oluşturur. Diyetisyenler, beslenme alanındaki bilimsel temelli bilgilerinin sınırlarını açıç̧a tanımlayabilirler. Dengesiz beslenme ya da obezite ile ilgili konularda sosyal hizmet uzmanlarının müdahale alanı diyetisyenler kadar açık ve çizgisi net değildir. Sosyal hizmet uzmanları, danışanları çevresi içerisinde ele alır ve sorunu sadece danışan odağında irdelemezler. Aynı zamanda obezitenin nedenlerini ve sonuçlarını da mikro, mezzo ve makro düzeyde değerlendirerek müdahalelerde bulunurlar (21,23,37). Sosyal hizmet uzmanları bu süreçte obez çocuğa diyetisyen tarafından verilen beslenme programına çocuk ve ailesinin uyum sağlamasında güçlük çekip çekmediğini araştırarak tedavi sürecini engelleyen etmenlerin üstesinden gelmelerine yardımcı olacak bireysel görüşmeler gerçekleştirebilirler. Aynı zamanda obezitenin çocukta yaratabileceği içe kapanıklık, özgüven eksikliği, depresyon gibi psikolojik (36) süreçler ile başa çıkmada, çocuk ve aile odaklı bireysel görüşmeler yürüterek mikro düzeyde müdahaleler yapabilirler. Mezzo düzeydeki müdahalelerde sosyal hizmet uzmanları, çocukta obeziteye neden olabilecek aile, okul, mahalle sistemlerini dikkate alırlar. Obez çocuğun beslenme sürecini en çok etkileyen ailenin yemek kültürünün obezite üzerindeki etkisini araştırarak diyetisyen işbirliğinde ailenin daha sağlıklı beslenmesi ve dolayısıyla istenen davranış değişikliği konusunda görev alabilirler. Okul yöneticileri ile biraraya gelerek çocukların daha fazla hareket edebilecekleri sportif faaliyetlere yer verilmesine ilişkin çalışmalar için diyetisyenlerle işbirliği yapabilirler (14-16).
Makro düzeyde ise sosyal hizmet uzmanları obezite ile mücadeleye yönelik toplumsal farkındalığı arttırıcı program ve politikaların geliştirilmesinde önemli rol oynayabilirler. Örneğin; çocukların ilgisini çeken sağlıksız besinlere ilişkin reklamların sinırlandırılmasına yönelik yasal düzenlemelerin yapılmasında diyetisyenlerle birlikte sorumluluk üstlenebilirler (16).

Sonuç olarak çocukluk çağında obezite ile mücadelede önemli bir yeri olan sosyal hizmet uzmanı ve diyetisyen işbirliği, çocukların sağlıklı yaşam yıllarını arttırmak için yapılması gereken mikro, mezo ve makro düzeydeki müdahalelerin daha etkili olmasına katkıda bulunabilir.

Çıkar çatışması - Conflict of interest: Yazarlar çıkar çatışması olmadığını beyan ederler. - The authors declare that they have no conflict of interest.

\section{KAYNAKLAR}

1. Serter R. Obezite Atlası. İstanbul: Tercih Kitabevi; 2003.s.13-14.

2. Türkiye Endokrinoloji ve Metabolizma Derneği. Obezite Tanı ve Tedavi Kılavuzu. Ankara: Miki Matbaacılık. 2019.s.11.

3. World Health Organization (WHO). Obesity and Overweight. Apr 1, 2020. Available at: https://www. who.int/en/news-room/fact-sheets/detail/obesity-andoverweight. Accessed Aug 11,2020.

4. Sağlık Bakanlığı. Obezite nedir? Available from: https:// hsgm.saglik.gov.tr/tr/obezite/obezite-nedir.html. Accessed Aug 10, 2020.

5. Türkiye Çocukluk Çağı (İlkokul 2. Sinıf Öğrencileri) Şişmanlık Araştırması (COSI-TUR 2016). Sağlık Bakanlığı, Halk Sağlığı Genel Müdürlüğü, Milli Eğitim Bakanlığı, Dünya Sağlık Örgütü Avrupa Bölge Ofisi, Sağlık Bakanlığı. Ankara: Efe Matbaacılık; 2017.

6. Mançu T, Smur G. Çocukluk çağı obezitesinin önlenmesi ve tedavisinde ulusal/uluslararası uygulamalar ve tedavi stratejileri. Beslenme ve Diyet Dergisi. 2015;43(2):14351.

7. Yılmazbaş P, Gökçay G. Çocukluk çağı obezitesi ve önlenmesi. Çocuk Dergisi. 2018;18(3):103-12.

8. Müller MJ, Danielzik S, Pust S. School-and familybased interventions to prevent overweight in children. Proceeding of the Nutrition Society. 2005;64(2):249-54.

9. Yardımcı H, Özdoğan Y, Özfer-Özçelik A, Hovland ED. 
Turkish adolescents' adherence to the Mediterranean diet. Anthropologist. 2016;25(1-2):174-79.

10. Deleş B. Çocukluk çağı obezitesi. H.Ü. Sağlık Bilimleri Fakültesi Dergisi. 2019;6(1):17-31.

11. Yayan EH, Çelebioğlu A. Obezojenik çevre ve çocukluk çağı obezitesine etkileri. ACU Sağlık Bil Derg. 2018;9(2):90-6.

12. Kline L, Jones-Smith J, Miranda JJ, Pratt M, Reis RS, Rivera JA, et al. A research agenda to guide progress on childhood obesity prevention in Latin America. Obes Rev. 2017;18(Suppl.2):19-27.

13. Eliadis EE. The role of social work in the childhood obesity epidemic. Social Work. 2006;51(1):86-88. Available from: https://academic.oup.com/sw/article-ab stract/51/1/86/1932410?redirectedFrom=PDF. Accessed Sept 1, 2020.

14. Collins S. Health practice update-The childhood obesity epidemic: the social work response. NASW (National Association of Social Worker). 2009. Washington, D.C. 20002-4241.

15. Koç N, Yardımcı H, Aslan NN, Uçaktürk SA. Nutritional habits and precocious puberty in girls: a pilot study. J Pediatr Res. 2018;5(4):201-8.

16. Köksal G, Gökmen Özel H. Çocukluk ve ergenlik döneminde obezite [Internet]. Ankara: Klasmat Matbaacılık; 2008 [cited 2020 Aug, 11].7-27p. Available from: https://sbu.saglik.gov.tr/Ekutuphane/kitaplar/t53. pdf.

17. Burke S. Childhood social factors and their impact on young adulthood obesity. Social Work Theses. 2011; 67. Available from: http://digitalcommons.providence.edu/ socialwrk_students/67. Accessed Aug 5, 2020.

18. Baysal A. Çocukluk çağı şişmanlığı. Beslenme ve Diyet Dergisi. 2016;44(2):88-9.

19. Keser A, Yüksel A, Yeşiltepe-Mutlu G, Bayhan A, Özsu E, Hatun Ş. A new insight into food addiction in childhood obesity. The Turkish Journal of Pediatrics. 2015;57(3):219-24.

20. Keser A, Yücecan S, Çizmecioğlu F, Etiler N, Hatun Ş. Çocukluk çağında metabolik sendrom ve beslenme örüntüsü arasındaki ilişkinin değerlendirilmesi. Beslenme ve Diyet Dergisi. 2008;36(1-2):9-22.

21. Shor R. Interdisciplinary collaboration between social workers and dieticians in nutrition education programs for children-at-risk. Social Work Health Care. 2010;49(4):345-61.

22. Melius J. Exploring social workers' use of the socioecological model as an intervention and research framework for treating overweight or obese clients. Social Work. 2015;60(1):55-63.

23. Lawrence S, Hazlett R, Hightower P. Understanding and acting on the growing childhood and adolescent weight crisis: a role for social work. Health Social Work.
2010;35(2):147-53.

24. Pappas C, Ai A, Dietrick B. Addressing childhood obesity using a multidisciplinary approach with social workers. Health Social Work. 2015;40(2):151-4.

25. Zengin O. Sosyal hizmetin sağlık hizmetlerinin sunumundaki rolü. Konuralp Tıp Dergisi. 2011;3(3):2934.

26. World Health Organization (WHO). Unhealthy diets \& physical inactivity (NMH Fact Sheet June 2009). 2009. Available from: https://www.who.int/nmh/publications/ fact_sheet_diet_en.pdf. Accessed Sept 17, 2020.

27. Lawrence SA, Abel EM, Stewart C, Dziuban C. Social work students' perceptions of obesity. Social Work Education. 2019;38(3):377-391.

28. Türkiye Beslenme ve Sağlık Araştırması (TBSA). 2017. Available from: https://balikesirism.saglik.gov. tr/TR,43758/2017-yili-turkiye-beslenme-ve-saglikarastirmasi.html. Accessed Aug 2, 2020.

29. Türkiye Beslenme ve Sağlık Araştırması (TBSA). 2010. Available from: https://hsgm.saglik.gov.tr/depo/birimler/ saglikli-beslenme-hareketli-hayat-db/Yayinlar/kitaplar/ diger-kitaplar/TBSA-Beslenme-Yayini.pdf. Accessed Aug 2, 2020.

30. Sağlık Bakanlığı, Hacettepe Üniversitesi Sağlık Bilimleri Fakültesi Beslenme ve Diyetetik Bölümü, T.C. Milli Eğitim Bakanlığı. Türkiye'de Okul Çağı Çocuklarında (610 Yaş Grubu) Büyümenin İzlenmesi Projesi Araştırma Raporu (TOÇBİ). Ankara: Kuban Matbaacılık; 2011.

31. Özer E. Diyabette tıbbi beslenme tedavisinin uygulanması ve diyetisyenin sorumlulukları. Beslenme ve Diyet Dergisi. 2019;47(Özel Sayı):5-14.

32. Topbaş M, Elmacioğlu F, Dündar C, Canbaz S, Pekşen Y. Obezite ile günlük tüketilen bazı besin öğeleri arasındaki ilişki. Beslenme ve Diyet Dergisi. 2000;29(2):62-7.

33. Bozbulut R, Keser A, Sürücüoğlu MS, Bideci A. Okul çağı çocuklarının beslenme durumları ile bazı biyokimyasal parametreleri arasındaki ilişki. Gümüşhane Üniversitesi Sağlık Bilimleri Dergisi. 2018;7(1):40-53.

34. Nguyen C, Bera K, Bota R, Hsu R. Biopsychosocial approach to the treatment of obesity: a retrospective review. J Obes Weight Loss. 2016;1(1):1-4.

35. Thompson N. Güç ve güçlendirme kuramı (Çev. N. Çalış). İçinde Çeviri Editörü. Ö. Cankurtaran. Güç ve güçlendirme, 1. Baskı. Ankara: Nika Yayınevi; 2016. p.[15-58].

36. Nieman P, LeBlanc CM, Canadian Paediatric Society, Healthy Active Living and Sports Medicine Committee. Psychosocial aspects of child and adolescent obesity. Paediatrics \& Child Health. 2012;17(4):205-6.

37. Buchbinder E, Eisikovitz Z, Karnieli-Miller O. Social workers' perceptions of the balance between the psychological and the social. Social Service Review. 2004;78(4):531-50. 